\title{
The Influence of Augmented Reality-Based Learning Media on the Students'Achievement of Mathematics
}

\author{
Gusti Ngurah Sastra Agustika ${ }^{*}$ \\ ${ }^{1}$ Primary School Teacher Education Study Program, FIP, Universitas Pendidikan Ganesha, Indonesia \\ *Corresponding author. Email: gn.sastra.a@undiksha.ac.id
}

\begin{abstract}
This study was aimed to determine the effectiveness of using augmented reality based learning media on mathematics competencies in elementary school. This study used a pre-experimental approach in learning geometry with the onegroup pretest-posttest design and the research subject was selected randomly. Before being given the treatment, the selected group of students was given a pretest to find out the students' prior knowledge about geometry. The selected group was taught about geometry by using augmented reality-based learning media and given posttest afterwards. The instrument used for data collection in this study was 40 valid and reliable items. Furthermore, from the posttest and pretest scores obtained a gain score using paired sample $t$ test to determine whether there were differences in knowledge competencies before and after using augmented reality-based learning media.The findings of the study revealed that the average posttest result was 87.89 and the pretest average result was 82.73 . The data was obtained the calculated value of 9.198, with $\mathrm{df}=31$ and $\alpha=0.05$, the $\mathrm{t}$ table value was 2.040. This results showed that there are significant differences in the students' mathematical competencies before and after using augmented reality based learning media.Since the average posttest is greater than the average pretest, it can be concluded that augmented reality-based learning media is effective to be applied as a learning media for elementary school.
\end{abstract}

Keywords: Mathematics Learning, Augmented Reality, Learning Media

\section{INTRODUCTION}

Mathematics has an important role in various aspects of life. In addition, mathematics is a scientific discipline that can improve thinking and argumentation skills, contribute to solving daily problems and in the world of work, and provide support in the development of science and technology [1]. Therefore, mathematics as a basic science needs to be mastered well by students starting from the primary school level.

Many problems and activities in life must be solved with mathematics, such as measuring, weighing, calculating, and so on which is used as a basic science needs to be mastered well by students starting from the primary school level. However, the teacher's efforts in providing learning experiences for students, especially in mathematics learning, have not yet provided learning outcomes of mathematical knowledge competencies as expected. This is known through data obtained from the UPT Office of Youth and Sports Education, South Denpasar District, that the average math score of students on the 2019 is 65.55 with category C. This result is lower than the average of other subjects such as Science and
Indonesian with a category $\mathrm{B}$ score. According to Permendikbud No.24 of 2016, one of the subject content at the elementary school level is mathematics and the scope of mathematics learning in elementary schools includes material on numbers, geometry and measurement and data processing.

Baran, Yecan, Kaptan, \& Paşayiğit [2] stated that students who are grouped usually face conflicts in using technology while in individual learning they are free to use technology without necessary conflicts. In the scope of goemetry, the use of interesting and interactive learning media is necessary for elementary school age students. Learning abstract concepts cannot be done only by transferring information, but it takes a concept formation process through a series of activities that students experience directly. Based on the current development of the industrial revolution which has entered the industrial era 4.0, where current conditions have affected various aspects of life including the field of education [3] then the learning media that is deemed necessary to be used is information technology-based learning media. 
Learning with the help of mobile technology has a positive impact which can increase the active role of students in mathematics [4]. One of the technologies that can combine virtual objects into a real view is Augmented Reality. Augmented Reality (AR) is an interactive visual technology that combines virtual objects into real-time views of the real world By utilizing AR technology and smartphones, geometric objects can be visualized through three-dimensional virtual modeling that resembles the real object. The acivities in AR provides many ambiguities which can explore students' imagination and improve their way of thinking. The complex stimuli engaged the focus of students for a longer period of time [5]. According to Yildirim [6], The application of AR improve the motivation as well as students' interest and make the learning becomes more mindful. The immediacy and immersion features offered in augmented reality learning is suitable for technology learning [2]. Students who learned mathematics through augmented reality showed positive attitude in the learning process. The activities shared in the AR learning media were interesting and make the students wanted to learn more [7].

Learning with the help of mobile technology has a positive impact which can increase the active role of students in mathematics [4]. Bicen \& Bal [8] stated that The use of AR in the classroom has made the course become enjoyable and students can easily access various information through their smartphone independently. Meanwhile, Azi \& Gündüz [9] found that there is no significant improvement in regards of students' learning achievement in experimental group that was taught by using AR between control group using smart board or current textbook.

Based on the previous explanation, problems related to low mathematics learning outcomes can be identified, namely due to the difficulty of teachers in providing various or varied concrete models to students about a learning material, especially in geometry. The use of Augmented Reality technology as a medium of learning to teach the sub-topic of geometric shapes in elementary school can be an alternative to help students understand various geometric objects, especially spatial shapes in more detail and fun. Therefore, this study will examine whether the use of mathematics learning media that utilizes Augmented Reality technology can have a good effect on the competence of mathematical knowledge on the subject of Geometry.

\section{THEORETICAL REVIEW}

\subsection{Mathematical Knowledge Competence}

Competence can simply be defined as a person's ability to effectively complete a task or job for which they are responsible. In the field of education, competence is defined as the ability to master knowledge, attitudes, and skills about a subject [10]. In line with this understanding, competence as a combination of skills, behavior and knowledge and basic values that can be demonstrated or reflected in the habits and abilities of students to think and act as results achieved through meaningful teaching and learning activities [11].

Knowledge competencies are competencies that must be achieved by students from the aspect of knowledge after participating in the learning process. Knowledge competencies are able to show students' abilities in understanding and mastery of learning material. In accordance with the previous explanation, knowledge competence is a competency that is able to show the level of mastery and understanding of students in aspects of knowledge obtained from the content of a material or subject matter after participating in the learning process. Thus the competence of knowledge is very influential on the achievement of competency standards of student graduates [12].

Mathematical skills are part of the life skills that students must have, especially in developing reasoning, communication, and solving problems faced in students' daily lives. In addition, mathematics has an important role in the development of science and technology. Student competence must have a graduate standard as a minimum requirement for the abilities possessed by students after participating in the learning process. Therefore, competence is related to learning outcomes during learning. Competence measured in the learning process consists of three aspects, namely knowledge competence, attitude competence and skills competence. Competencies that measure mastery related to the theory of learning material are knowledge competencies.

\subsection{Learning Media}

The notion of learning media is conveyed by many experts in the field of learning media [13]. The word media which comes from the Latin medium, which means intermediary. So that the word media is interpreted as an intermediary between the sender of information who functions as a source and receiver of information. Media is an intermediary for messages from sender to message recipient. So television, films, photos, radio, audio recordings, projected images, printed materials and the like are communication media. If the media carries messages or information that are instructional or contain teaching purposes, the media is called learning media [14].

Learning media are defined as media as all forms and channels used to convey messages or information. Media is also often called a mediator, with the term media mediator showing its function or role, namely regulating an effective relationship between the two main parties in the learning process, namely students and the content of the lesson. 
Learning media is a combination of materials and tools or a combination of software and hardware [15]. Learning media can be used in the process and learning objectives. The learning process is also a communication, so learning media can be understood as a communication medium used in the communication process, learning media has an important role as a means of channeling learning messages.

Media is divided into two categories, namely instructional aids and instructional media [16]. Learning media are used to clarify the material (message) to be conveyed. Therefore, learning aids are also called teaching aids.

The characteristics of learning media in general can be grouped into three [17], that is:

1) Fixative Properties Learning media has the ability to record, store, preserve, and reconstruct an event or object.

2) Manipulative Characteristics (Manipulative Property) Learning media can take advantage of technological sophistication to manipulate an event or object. Events that are long lasting, can be shortened or only show important events. Objects in the real world can be manipulated so that they become models in 3D.

3) Distributive Characteristics (Distributive Property) Learning media is used so that events or objects in one place can be spread to other places easily. The event or object can be presented in the classroom without students having to visit it in person, for example through films, photos and video recordings.

\subsection{Functions and Benefits of Learning Media}

The use of instructional media in the learning orientation will greatly help the learning process and convey the message and content of the lesson at that time. In addition to arousing student motivation and interest, learning media can also help students improve understanding, present data in an interesting and reliable manner [18]. Learning media is very important because learning media can bring and arouse joy for students and renew their enthusiasm, help strengthen knowledge in students and bring learning to life [19].

Levie \& Lentsz suggests four functions of learning media, especially visual media, namely: Attention Functions, Affective Functions, Cognitive Functions, Compensatory Functions.

1. The function of visual media attention is the core which is to attract and direct students' attention to concentrate on the subject matter related to the visual meaning that is displayed or accompanies the text of the subject matter. Often at the beginning of the lesson students are not interested in the subject matter or subjects that are not liked by them so they do not pay attention. Projected visual media can calm and direct their attention to the subjects they will receive. Thus, the possibility of obtaining and remembering the content of learning material is greater.

2. The affective function of visual media can be seen from the level of enjoyment of students when learning or reading pictorial text. Visual images or symbols can inspire students' emotions and attitudes.

3. The cognitive function of visual media seen from visual symbols or images facilitates the achievement of goals to understand and remember the information or messages contained in the image.

4. The compensatory function of learning media can be seen from the research results that visual media that provide context for understanding the text helps students who are weak in reading to organize information in the text and remember it again. In other words, the learning media serves to accommodate students who are weak and slow to accept and understand the content of the lessons presented with text or presented verbally.

\subsection{Augmented Reality in Learning}

Augmented realityis a technology that is able to combine two-dimensional or three-dimensional virtual objects in a real environment and then project these virtual objects in real-time [20]. This technology has been widely used in the fields of military, pharmaceuticals, manufacturing, robotics, education and so on. AR is able to provide interesting interactions that were not possible before. We can interact with fingers on virtual objects. These interactions can take the form of changing the shape of the object, changing the position of the object, and other movements that cause the graphics to change [8].

Users can move 3-dimensional objects in the form of virtual objects, see them from various positions according to the user's wishes like real objects [21]. The information contained in the virtual object displays the real information contained in the real world. The advantages of using AR technology in learning include:

1) Easy to develop both for teachers and students as it is based on Android. Android itself is open source, so to develop it does not cost money.

2) Reducing the burden of teaching materials, such as books, Mathematical models in the form of wooden blocks, Globe models for geography lessons, and so on.

3) The learning process can be done anywhere and anytime.

4) Make the teaching and learning process more interesting. Keep up with technological developments 
and attract students' interest in mobile technology. So that students can use the gadgets they have properly.

By using AR technology, students can see and manipulate geometric concepts related to space, so that students feel interested in learning and can understand the concept of space well [22]. In addition, by using AR technology as a learning medium, students can learn and manipulate the objects presented in AR so that students can study regularly at home or anywhere until students are able to construct their knowledge [9]. In addition, Augmented Reality is able to provide a picture or information that can be more easily understood, therefore Augmented Reality can be used for learning applications [22]. Based on these thoughts, the use of AR-based mathematics learning media in the learning process will be able to provide a good influence on students in constructing their knowledge related to learning materials for Geometry in elementary schools.

The learning process in elementary schools should be well designed in order to provide a pleasant and meaningful learning experience. Especially in learning mathematics in elementary schools, it is necessary to make innovations that can give pleasure in learning materials related to mathematics, because so far mathematics is considered a difficult subject and is always related to formulas or other abstract objects.

Based on the explanation of the previous theory that mathematics is one of the disciplines whose field of study is an abstract object, it requires an introductory medium that can visualize these abstract concepts. The role of learning media is very important to be able to help students understand the concepts being learned. Especially in Geometry, a learning media is needed that can provide concrete forms of abstract concepts [23]. Conventional learning media that are often used to teach the concept of space are surrounding objects that have a shape similar to the concept of the intended space. Current technological advances can be used to create a learning medium that can visualize abstract space concepts into a real, manipulable environment which is often referred to as augmented reality.

Currently the use of AR media as a learning medium has a good impact. This has been presented by several studies that tried AR-based learning media. Among them is research by Affix Mareta in 2015 regarding the application of Augmented Reality teaching media which concluded that the media can be implemented properly and can have a good impact. Another study that developed mathematics teaching materials with the help of Augmented Reality, concluded that the teaching media received a good response from students and teachers so that it could be used in learning [24].

\section{METHOD}

This research is a pre-experimental research which did not use a control group nor did it pay attention to the experimental principles in full as the result of the widespread spread of COVID-19 that the learning process which is carried out face-to-face in class must be changed into the form of online learning which is carried out independently at each student's home. Based on the conditions in the field, the research design used was the one-group pretest-posttest design based on Campbell and Stanley's (1963) model which can be described as follows:

\section{$\mathrm{O} 1 \times 02$}

Figure 1. "The One-Group Pretest-Posttest Design"

Information:

$\begin{array}{ll}\mathrm{X} & \text { : Learning treatment using AR media } \\ \mathrm{O} 1 & \text { : Pre Test } \\ \mathrm{O} 2 & \text { : Post Test }\end{array}$

Before being given treatment using AR learning media, each student was given a pretest to measure students' understanding of the topic of Geometry. After being given a pretest, students will use the learning media in the form of AR to study the Geometry and after that they will be given a posttest to measure students' understanding of the Geometry.

The population in this study were all students of fifth grade elementary schools in the Sudirma General Cluster of South Denpasar in the 2019/2020 school year, which consisted of 5 public schools. The sampling technique used was probability sampling with a cluster random sampling design. Sampling with a cluster random sampling design was carried out by randomizing all members of the population consisting of 5 schools. The sampling process is carried out the first time is to make a lottery for the experimental group, the school that is selected will be used as an experimental group.

The variables in this study consisted of 3 variables. 1 dependent variable, namely the competence of Mathematics knowledge, 1 independent variable, namely the learning model. For the purposes of this study, each variable will be operationally defined as follows:

1. Mathematical knowledge competence is the level of achievement and mastery of a mathematics learning material achieved through teaching and learning activities and measured using tests to obtain a score.

2. Augmented Reality (AR) based learning media is a medium that uses technology to combine 3dimensional virtual objects into a real environment and project these virtual objects in real time which are used to help students understand and construct 3dimensional Geometry. 
In this study, the data collection technique used was a test which is a tool or procedure used to find out or measure something in an atmosphere, by means, and predetermined rules [25]. Before being used as a data collection tool, the test is tested for validity, difference power, difficulty index, and reliability, in order to obtain valid and steady data. Testing the validity of the test used the biserial point correlation formula and the reliability coefficient was calculated using the KR-20 coefficient formula.

The instrument used to measure the competence of students' mathematical knowledge is a test instrument in the form of a multiple choice objective test. In a multiple choice objective test, there is the possibility of wrong and correct answers and there is only one correct answer choice. Each question presented in the test has four answer choices (a, b, c, and d). Every question that is answered correctly will have a score of one and a score of zero if the student's answer is wrong. To determine the appropriateness of the instruments used, validity and persistence tests were carried out.

The research data was obtained in the form of an interval scale which was then analyzed using parametric statistics, namely the t-test. To be able to test the hypothesis with the t-test, the prerequisite analysis test is conducted first, namely the normality test and the homogeneity test. The following sub-chapters will explain the stages of hypothesis testing carried out.

\subsection{Normality Test}

This parametric statistic works based on the assumption of data for each variable to be analyzed based on a normal distribution. The normality test is intended to determine whether the data distribution of the competency scores of students' mathematical knowledge in each group is normally distributed or not so that it can determine the data analysis technique. Test the normality of the data distribution in this studyusing the Kolmogorov-Smirnov technique.

\subsection{Hypothesis Testing}

The statistical analysis used to test the research hypothesis was the t-test for the independent groups. So that the research hypotheses tested in this study are:

H0: There is no difference in the competence of mathematics knowledge of fifth grade students before using AR-based learning media and the competence of mathematics knowledge of fifth grade students after using AR-based learning media.

The statistical hypotheses tested in this study are:

$$
\mathrm{H} 0: \mu 1=\mu 2
$$

Information:

$\mu 1=$ average mastery of students' mathematical knowledge competencies before using ARbased learning media

$\mu 2=$ average mastery of students' mathematical knowledge competencies after using AR-based learning media

If the data obtained has met the prerequisites for normality and homogeneity tests, the analysis used is parametric statistics. The statistical analysis used to test the research hypothesis is the mean difference test ( $\mathrm{t}$ test). Hypothesis testing using t-test with the polled variance formula. The formula for $47 \mathrm{t}$-test with the polled variance formula is used when the number of sample members is equal to $\mathrm{n} 1=\mathrm{n} 2$ and the variance is homogeneous. The t-test formula with the polled variance formula is as follows.

$t=\frac{\bar{X}_{D}-\mu_{D}}{S_{D} / \sqrt{n}}$

Information:

$\bar{X}_{D} \quad=$ average the difference between the pretest score and the posttest score

$\mu_{D} \quad=$ hypothesized value

$s_{D} \quad=$ standard deviation of the difference between pretest and posttest

$\mathrm{n} \quad=$ number sstudent data

\subsection{Calculating Effectiveness}

The magnitude of the effectiveness of the use of ARbased learning media on the competence of students' mathematical knowledge can be done by calculating the Cohen's d coefficient. According to Cohen (in Gravetter and Wallnau, 2014) effectiveness can be standardized by measuring the average difference in standard deviation units. The Cohen's d coefficient can be calculated by the following formula.

$\mathrm{d}=\frac{M_{\text {treatment }}-M_{\text {no-treatment }}}{s_{D}}$

Information:

$\mathrm{d}=$ effectiveness value

Mtreatment=average value post-test (after treatment) Mno-treatment=average value pre-test(before treatment) $S_{D}=$ standard deviation

The value of $d$ illustrates the magnitude of the effectiveness of the independent variables applied to the experimental group on one dependent variable. Big criteria Cohen'd coefficient classified as follows:

a. $\quad 0<\mathrm{d}<0.2=$ Small effect (difference in mean less than 0.2 standard deviation) 
b. $0.2<\mathrm{d}<0.8=$ Moderate effect (difference to the average of about 0.5 standard deviation)

d $>0.8=$ Large effect (difference in mean more than 0.8 standard deviation)

\section{FINDINGS}

\subsection{Data Description}

This research is a pre-experimental research which aims to determine the effectiveness of augmented reality based mathematics learning media. The pre-experimental design used was the one-group pretest-posttest design. This design uses a group given treatment. To determine the effectiveness of learning media, it is done by comparing the pretest scores before using learning media and after using learning media. Therefore, the following sub-chapters describe the pretest data before being given learning media and posttest data after being given learning media.

\subsection{Data Description}

Before being given treatment, students were measured their mathematical knowledge related to Geometry in elementary schools. The instrument used to measure mathematical knowledge is a math test with 40 multiple choice questions. From the pretest results obtained data presented in graphical form as follows:

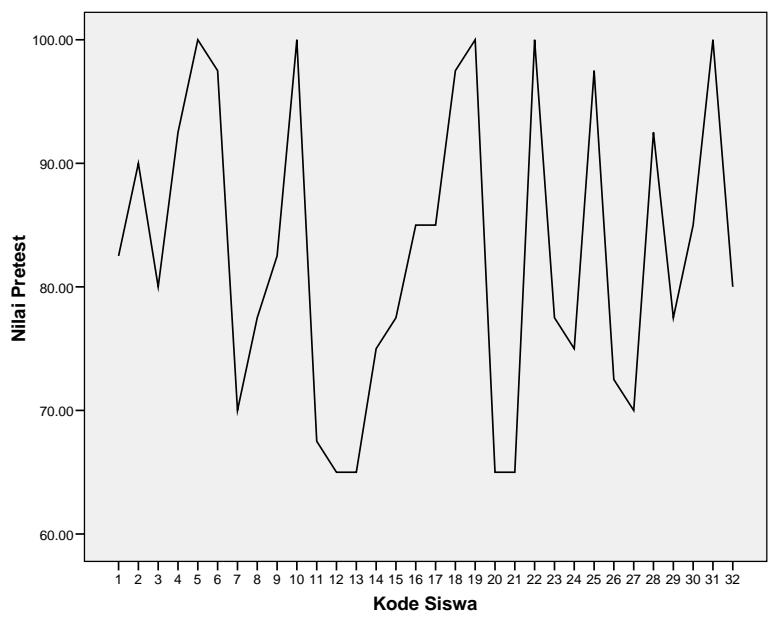

Figure 2 Graph of Pretest Value

Based on Figure 2, it can be seen that as many as 4 students get grades below 70, and most of the students scored above 80 . To be clearer about the description of the data for the pretest scores of students, the following is a summary of statistics for the pretest data which is presented in table form as follows:
Table 1. Descriptive Statistics of Pretest Data

\begin{tabular}{|l|r|r|r|r|r|r|r|r|}
\hline & $\mathrm{N}$ & Range & Minimum & $\begin{array}{c}\text { Maximu } \\
\mathrm{m}\end{array}$ & Sum & Mean & Sto. Deviation & Variance \\
\hline $\begin{array}{l}\text { Pretest Value } \\
\text { Valid N }\end{array}$ & 35.00 & 65.00 & 100.00 & 2647.50 & 82,7344 & 12,13764 & 147,322 \\
(listwise) & 32 & & & & & & & \\
\hline
\end{tabular}

Based on Table 1, it is known that the lowest data for the pretest score is 65 while the highest score is 100.Based on Figure 4.1 it is also known that the value most students get is 100 . Based on Table 4.1 it is known that the data is centered around a score of 82.73 with a standard deviation equal to 12.13 , which means that the data is spread around the value of 82.73 .

\subsection{Posttest Data Description}

After being given treatment, students were again measured for their mathematical knowledge related to Geometry in elementary schools. The instrument used to measure mathematical knowledge is the same math test as the pretest before treatment. From the results of the posttest, the data is presented in graphical form as follows:

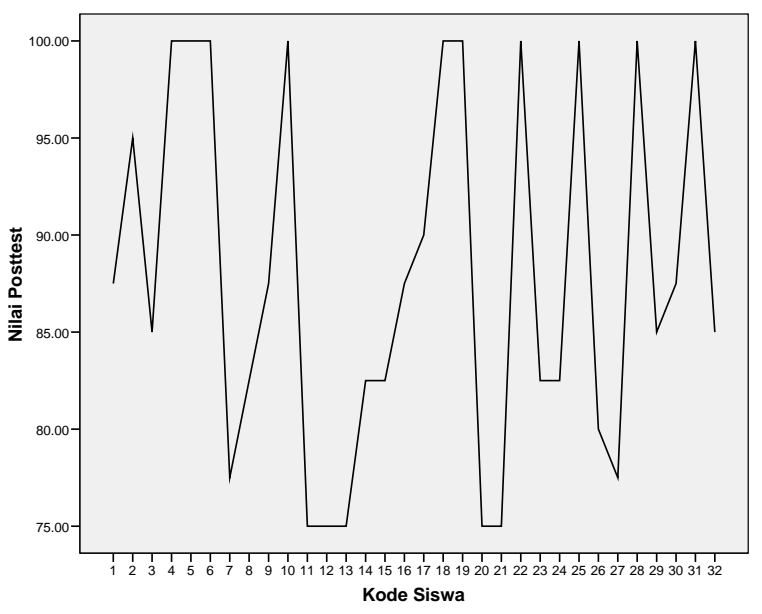

Figure 3 Posttest Value Graph

Based on Figure 3, it can be seen that as many as 4 students got a score of 75 , and most of the students got a score above 80 and as many as 9 students got a score of 100. Table as follows:

Table 2. Descriptive Statistics of Posttest Data

\begin{tabular}{|l|l|r|r|r|r|r|r|r|}
\hline & $\mathrm{N}$ & Range & Minimum & $\begin{array}{c}\text { Maximu } \\
\mathrm{m}\end{array}$ & Sum & Mean & Std. Deviation & Variance \\
\hline Posttest Value & 32 & 25.00 & 75.00 & 100.00 & 2812.50 & 87,8906 & 9,50614 & 90,367 \\
\hline Valid N (listwise) & 32 & & & & & & & \\
\hline
\end{tabular}

Based on Table 2, it is known that the lowest data for the pretest score is 75 while the highest value is 100 . Based on Table 2, it is also known that the data is centered around a score of 87.89 with a standard deviation of 9.5 , which means that the data is spread around the value of 87.89 . 


\subsection{Description of Score Gain Data}

The score gain data is the data obtained from the difference between the posttest and pretest scores. In this study, the effect of learning media is seen from the change in value before using augmented reality-based learning media and after using augmented reality-based learning media. Because the data analyzed to test the hypothesis is the score gain data, the following section discusses the score gain data obtained from the difference between the posttest and the pretest. The score gain data is presented in graphical form as in Figure 4.

Based on Figure 4, it is known that most of the students experienced an increase in their scores before using augmented reality media. There are 5 students who do not experience an increase because the pretest and posttest scores have reached the ideal maximum value of 100.

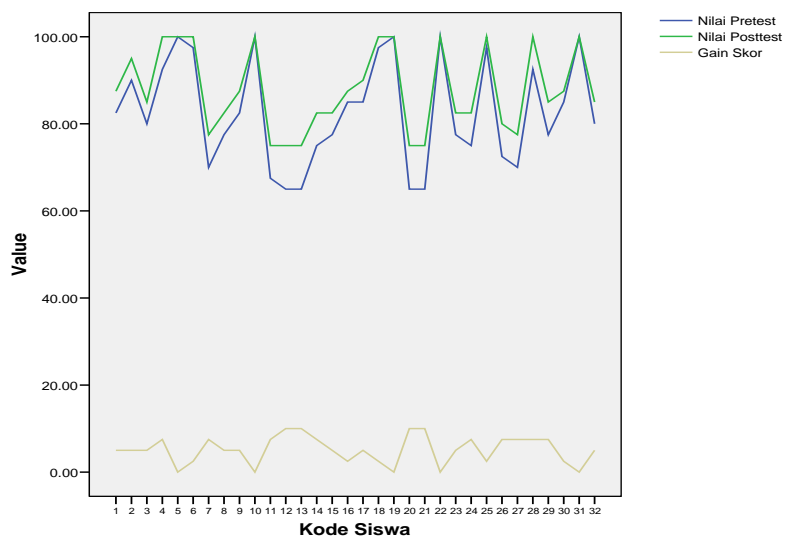

Figure 4 Score

\subsection{Assumption esting}

Prerequisite analysis tests need to be carried out to ensure that the results of tests carried out using parametric statistics are acceptable. The prerequisite test that needs to be done so that the data can be analyzed using the paired data t-test is the normality test which will be presented in the following section.

\subsubsection{Normality Test}

The data normality test is carried out to determine whether the data is normally distributed or not. In this study, the normality test was carried out using the Kolmogorov Smirnov. The results of the Kolmogorov Smirnov test for score gain data are as follows:
Table 3. Kolmogorov Smirnov Test Results

\begin{tabular}{|l|l|r|}
\hline \multicolumn{2}{|l|}{} & \multicolumn{1}{c|}{ Score Gain } \\
\hline N & Mean \\
\hline $\begin{array}{l}\text { Normal } \\
\text { Parameters (a, b) }\end{array}$ & 5,1563 \\
\hline & Std. Deviation & 3,17103 \\
\hline $\begin{array}{l}\text { Most Extreme } \\
\text { Differences }\end{array}$ & Absolute &, 176 \\
\hline & Positive &, 113 \\
\hline & Negative &,- 176 \\
\hline Kolmogorov-Smirnov Z &, 997 \\
\hline Asymp. Sig. (2-tailed) &, 273 \\
\hline
\end{tabular}

Based on the results of the Kolmogorov-Smirnov test it is known that the significance is 0.273 . Because the significance obtained is greater than the alpha taken by $5 \%$ or 0.05 , the conclusion is that the score gain data follows a normal distribution.

\subsection{The Effectiveness of Learning Media}

Based on the post test and pretest data that has been obtained, it is known that the average post test is 87.89 and the pretest average is 82.73 with a pooled standard deviation of 10.9, the cohen D effectiveness coefficient is 0.473 . Based on the classification of the cohen D coefficient category, it can be said that the use of Augmented Reality-based learning media has moderate effectiveness. From these results, of course the use of learning media is very important to help students understand the material by providing illustrations and providing opportunities for students to explore the concepts given so that students' understanding of the concepts is getting better.

\subsection{Hypothesis Test}

After it is declared that it meets the prerequisites for the analysis test, the next step is to test the hypothesis using the $\mathrm{t}$-test. The hypothesis tested in this study using the $\mathrm{t}$-test is as follows:

H0: There is no difference in the competence of mathematics knowledge of fifth grade students before using AR-based learning media and the competence of mathematics knowledge of fifth grade students after using AR-based learning media.

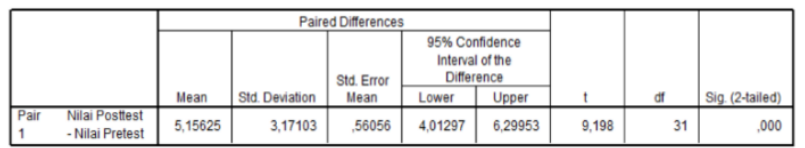

Figure 5 SPSS Output Paired t-Test Data

Based on the results of the analysis with the data $t$ test pairwise note that the 2 -sided significance value is 0.000 . because the significance value obtained is less than alpha 
of 0.05 , then $\mathrm{HO}$ is rejected and $\mathrm{Ha}$ is accepted. So it can be concluded that there are differences in the competence of mathematics knowledge of fifth grade students before using AR-based learning media and the competence of mathematics knowledge of fifth grade students after using AR-based learning media. Since the $t$ value is positive, it can be concluded that the average posttest score is greater than the average pretest score.

\section{DISCUSSION}

The use of augmented reality-based learning media can have a positive influence on students' understanding of the concept of Geometry at the level of primary school education, especially in fifth grade students amounting to 82.73 and 87.89 , respectively. From the results of data analysis with the $t$ test, it was found that there was a significant difference in mathematics knowledge competence before being taught using augmented reality based learning media and mathematics knowledge competence after being taught using augmented reality based learning media. Another experiment using augmented reality media also found similar results [26]. In different subject areas, the use of augmented reality can also improve student learning outcomes in learning Hinduism in elementary schools [27]. So that in general, augmented-based learning media has a positive effect on improving students' understanding of a particular concept.

The use of augmented reality based learning media is very good if it is applied in the learning process. From the observations of students who use augmented reality media, it looks more focused on learning, and students look serious in following the instructions contained in the augmented reality based learning application. In addition, learning media based on augmented reality can accommodate students who are slow to accept learning, this is because students can learn independently and repeat the concepts conveyed through augmented reality media until students understand them. This can be seen from some students who tried several times for one concept conveyed in the learning media.

Based on the experimental results, it is known that student learning outcomes after using augmented reality media have increased significantly. This means that the augmented reality media used is able to make students focus on learning so that an effective learning process occurs so that the information to be conveyed can be received by students properly. This is because the learning media not only has a major effect on the learning process and outcomes, but also can increase motivation and enthusiasm for learning (Kozma, 1991). So that the better and more suitable the media is in the learning process, the more effective and efficient the learning process is and the better student learning outcomes.

\section{CONCLUSION}

Based on the results of data analysis using the t test, it can be concluded that the use of augmented realitybased learning media has an effect on the mastery of competence in mathematics knowledge of fifth grade students that can be seen from the posttest score is 87.89 and the pretest score is 82.73 . The effect that occurs is a positive influence, which means that it can be used as a learning aid to improve the competence mastery of students' knowledge about geometry geometry. The positive effect of using learning media based on augmented reality can be seen from the better posttest results than the pretest results. The influence occurs because the augmented reality learning media is able to make students focus on learning and students can learn concepts independently through manipulation of learning media. So that the concept to be conveyed to students can be accepted well.

\section{AUTHORS' CONTRIBUTIONS}

This research is useful for making students more active in solving problems related to mathematics subjects. In addition, the results of this study can also be useful for the development of Augmented Reality technology based on the Android system since this study is expected to be used as a reference for the use of various learning media, especially in the use of augmented reality technology based on the Android system on the subject of geometry in fifth grade elementary students which can affect the competence of their mathematical knowledge.

\section{ACKNOWLEDGMENTS}

This research was supported by a grant from LPPM Universitas Pendidikan Ganesha.

\section{REFERENCES}

[1] M. A. Borba, P. Askar, J. Engelbrecht, G. Gadanidis, S. Llinares, M. S. Aguilar, Blended learning, elearning and mobile learning in mathematics education, ZDM - Mathematics Education 48(5) (2016) 589-610. DOI: https://doi.org/10.1007/s11858-016-0798-4

[2] B. Baran, E. Yecan, B. Kaptan, O. Paşayiğit, Using augmented reality to teach fifth grade students about electrical circuits, Education and Information Technologies 25(2) (2020) 1371-1385. DOI: https://doi.org/10.1007/s10639-019-10001-9

[3] J. Martin, J. Bohuslava, H. Igor, Augmented reality in education 4.0, 2018 IEEE 13th International Scientific and Technical Conference on Computer Sciences and Information Technologies, CSIT 2018 - Proceedings, 1, 2018, PP. 231-236. DOI: https://doi.org/10.1109/STC-CSIT.2018.8526676 
[4] A. Bray, B. Tangney, Enhancing student engagement through the affordances of mobile technology: a 21st century learning perspective on Realistic Mathematics Education, Mathematics Education Research Journal 28(1) (2016) 173-197. DOI: https://doi.org/10.1007/s13394-015-0158-7

[5] D. A. Ismaeel, E. N. Al Mulhim, Influence of Augmented Reality on the Achievement and Attitudes of Ambiguity Tolerant/Intolerant Students, International Education Studies 12(3) (2019) 59.5 DOI: https://doi.org/10.5539/ies.v12n3p59

[6] F. S. Yildirim, The Effect Of The Augmented Reality Applications In Science Class On Students' Cognitive And Emotional Learning, Journal of Education in Science, Environment and Health, 2020. DOI: https://doi.org/10.21891/jeseh.751023

[7] E. Demitriadou, K. E. Stavroulia, A. Lanitis, Comparative evaluation of virtual and augmented reality for teaching mathematics in primary education, Education and Information Technologies 25(1) (2020) 381-401. DOI: https://doi.org/10.1007/s10639-019-09973-5

[8] H. Bicen, E. Bal, Determination of student opinions in augmented reality, World Journal on Educational Technology 8(3) (2016). DOI: https://doi.org/10.18844/wjet.v8i3.642

[9] F. B. Azi, Ş.Gündüz, Effects of Augmented Reality Applications on Academic Success and Course Attitudes in Social Studies, Shanlax International Journal of Education 8(4) (2020) 27-32. DOI: https://doi.org/10.34293/education.v8i4.3300

[10] M. Keinänen, J. Ursin, K. Nissinen, How To Measure Students Innovation Competences In Higher Education: Evaluation Of An Assessment Tool In Authentic Learning Environments, Studies In Educational Evaluation 58(5) (2018) 30-36. DOI: https://doi.org/10.1016/J.Stueduc.2018.05.007

[11] A. A. Karim, A. Abduh, D. Manda, M. Yunus, The effectivity of authentic assessment based character education evaluation model, TEM Journal 7(3) (2018 ) 495-500. DOI: https://doi.org/10.18421/TEM73-04

[12] L. Darling-Hammond, J. Snyder, Authentic Assessment Of Teaching In Context, Teaching and Teacher Education 16(1) (2000) 523-545.

[13] A. J. Moreno, M. M. Klute, Infant - Toddler Teachers Can Successfully Employ Authentic Assessment: The Learning Through Relating System, Early Childhood Research Quarterly 26(2)
(2011) 484-496. DOI: https://doi.org/10.1016/J.Ecresq.2011.02.005

[14] R. B. Kozma, Learning with Media, Review of Educational Research, 61(2) (991) 179-211. DOI: https://doi.org/10.3102/00346543061002179

[15] C. L. Chiang, H. Lee, The Effect of Project-Based Learning on Learning Motivation and ProblemSolving Ability of Vocational High School Students, International Journal of Information and Education Technology 6(9) (2016) 709-712. DOI: https://doi.org/10.7763/ijiet.2016.v6.779

[16] D.P. Parmiti, and S, M, Pengembangan Perangkat Pembelajaran, Proceeding Senari, 29(1) (2014) 8895. DOI: https://doi.org/P-Issn:2089-5003

[17] Musakkir, Pengaruh Media Pembelajaran dan Motivasi Belajar Sekolah Dasar Kabupaten Tanah Tidung Musakkir Sekolah Dasar 001 Sesayap Kabupaten Tanah Tidung Mata Pelajaran Matematika Diberikan Kepada Peserta Didik Mulai dari Sekolah Dasar Untuk Membekali Peserta Didik, Jurnal Pendidikan Dasar, 6, 2015.

[18] W. B. Sulfemi, Model Pembelajaran Kooperatif Mind Mapping Berbantu Audio Visual dalam Meningkatkan Minat, Motivasi Dan Hasil Belajar IPS, Jurnal Pendidikan Ilmu Pengetahuan Sosial Indonesia 4(1) (2019) 13-19.

[19] A. Susilawati, H. Hernani, P. Sinaga, The Application of Project-Based Learning Using Mind Maps To Improve Students' Environmental Attitudes Towards Waste Management in Junior High Schools, International Journal of Education, 9(2) (2017) 120-125. DOI: https://doi.org/10.17509/ije.v9i2.5466

[20] J. Cabero-Almenara, J. Barroso-Osuna, C. LlorenteCejudo, M. M. F. Martínez, Educational uses of augmented reality (AR): Experiences in educational science, Sustainability (Switzerland) 11(18) (2019) 1-18. DOI: https://doi.org/10.3390/su11184990

[21] A. Susilawati, H. Hernani, P. Sinaga, the Application of Project-Based Learning Using Mind Maps To Improve Students' Environmental Attitudes Towards Waste Management in Junior High Schools, International Journal of Education 9(2) (2017) 120-125. DOI: https://doi.org/10.17509/ije.v9i2.5466

[22] N. Supriono, F. Rozi, Pengembangan Media Pembelajaran Bentuk Molekul Kimia Menggunakan Augmented Reality Berbasis Android, JIPI (Jurnal Ilmiah Penelitian Dan Pembelajaran Informatika) 3(1) (2018) 53-61. DOI: https://doi.org/10.29100/jipi.v3i1.652 
[23] A. Ningtias, A. Hartoyo, D. Suratman, Media Augmented Reality Berbasis Android Dalam Materi Bangun Ruang Sisi Datar Siswa SMP, 2013, pp. 111.

[24] P, K. H. B., A. Buchori, and A. N. Aini, Pengembangan Media Pembelajaran Berbasis Android Menggunakan Augmented Reality Pada Materi Bangun Ruang Sisi Datar, Jurnal Pendidikan Matematika Dan Sains 6(1) (2018) 61-69.

[25] T. Monita, R. D. Sari, M. Randikai, A. Ibrahim, Analisis Pengaruh Minat Belajar Siswa Terhadap Media Pembelajaran Berbasis Augmented Reality, POSITIF : Jurnal Sistem Dan Teknologi Informasi 5(1) (2019) $34 . \quad$ DOI: https://doi.org/10.31961/positif.v5i1.675

[26] J. Poerwanti, T. Budiharto, S. Marmoah, The Influence of Interactive Learning Media Based on Augmented Reality on the Achievement of Art Learning Result, 2019. DOI: https://doi.org/10.4108/eai.27-4-2019.2286858

[27] I. P. A. Saskara, Pengaruh Augmented Reality Senjata Dewata Nawa Sanga sebagai Media Pembelajaran Interaktif Terhadap Pembelajaran Agama Hindu Di SD Negeri 2 Pererenan, Widya Duta: Jurnal Ilmiah Ilmu Agama Dan Ilmu Sosial Budaya 14(2) (2020) 20. DOI: https://doi.org/10.25078/wd.v14i2.1226 